\title{
The potential of Imbrasia belina worm as a poultry and fish feed. A review
}

\author{
S. Moyo ${ }^{1,3}$, P.J. Masika ${ }^{2,4}$ and V. Muchenje ${ }^{1}$ \\ ${ }^{1}$ University of Fort Hare, Faculty of Science and Agriculture, Department of Livestock and Pasture Sciences, \\ Private Bag X1314, Alice 5700, South Africa \\ ${ }^{2}$ Fort Cox Agricultural and Forestry Training Institute, P.O. Box 2187, King Williams Town 5600, South Africa \\ ${ }^{3}$ Gwanda State University, Faculty of Life Sciences, Department of Animal Science, \\ Epoch Mine Campus, P.O. Box 30, Filabusi, Zimbabwe
}

KEY WORDS: availability, Imbrasia belina, feeds, nutrition, protein, sustainability

Received: 25 October 2018

Revised: $\quad 1$ July 2019

Accepted: 16 September 2019

${ }^{4}$ Corresponding author:

e-mail: patrick.masika@gmail.com

\begin{abstract}
This review is aimed to present the potential of Imbrasia belina as poultry and fish feed. Imbrasia belina worms contain substantial amounts of proteins, fats, essential amino acids, fatty acids, minerals and carbohydrates useful for the animal health. The worm as a source of protein could be utilised to minimise inadequate nutrition in poultry and fish. It has been documented as feed for such animals as fish, broilers, layers and guinea fowl. Imbrasia belina worm is an alternative source of animal protein, which is locally available, accessible and acceptable as food and feed source. However, using Imbrasia belina worm as animal feed has also some disadvantages as: chitin, the risk of being over exploited, unpalatability and a chance of indigestibility at higher inclusion levels in diets. Therefore, in this review the potential of $I$. belina worm as poultry and fish feed is assessed.
\end{abstract}

\section{Introduction}

Livestock feeding is known as a chief contributor to climate change, energy use, water dependence and land occupation (Mungkung et al., 2013). The production of soybean and fish meal rises these problems. Monogastric species like fish and poultry require high values and amounts of protein in their diet (Sánchez-Muros et al., 2014). From nutritional perspective, protein sources ought to have high-protein content, an adequate amino acid profile, high digestibility, good palatability and no anti-nutritional factors (Barrows et al., 2008). Hence fish and soybean meal are the main valuable protein sources in fish and poultry diets (Sánchez-Muros et al., 2014).

Furthermore, Sotak-Peper et al. (2017) pointed that soybean meal is a high digestible and high quality protein with favourable amino acid profile that can be used in animal feeding. However, it has several unfavourable traits, which include disparities between dispensable and indispensable amino acids, anti-nutritional factors, low palatability and high proportions of fibre and non-starch polysaccharides limiting the percentage inclusions in the diet (Sánchez-Muros et al., 2014). As a result, it is necessary to complete the diet by adding amino acids or high value protein source such as fish meal having also excellent nutritive properties. These benefits, together with the present regulations forbidding the usage of meat meals due to problems of food security, enable fish meal to be highly utilised. However, the massive use of soybean poses severe environmental issues, such as deforestation of high biological value areas, high water usage (Steinfeld et al., 2006), utilisation of insecticides, fertilisers and varieties whose genes have been artificially 
inserted (Garcia and Altieri, 2005) causing environmental deterioration. While fish meal is a resource that is governed on catch, hence its manufacture is quantitative and qualitatively variable (FAO, 2012). The stock has been declining due to global climate change leading to reduction in the manufacture of fish meal and price escalation of varieties whose genes have been artificially inserted. This situation is likely to linger (International Monetary Fund, 2010) with consequent repercussions on animal production. Hence this situation calls for alternative sources of proteins, which are vital for fish and poultry diets (Manzano-Agugliaro et al., 2012). Such potential protein source can be Imbrasia belina worm which can cater for amino acids deficiency in soybean. Imbrasia belina worm meal is highly digestible and has good balance between essential and non-essential amino acids (Sánchez-Muros et al., 2014).

Currently worms like I. belina are a novel protein source for poultry and fish (Premalatha et al., 2011; van Huis et al., 2013). When utilising insects as livestock feed, factors including the natural feeding habit of many species such as poultry and cultivated species of fish are considered. Conversely, there is limited documentation on I. belina being utilised as poultry and fish meal, despite its nutritive value potential. This review seeks to divulge the potential use of I. belina as poultry and fish feed.

\section{Description and life cycle of $I$. belina worm}

Imbrasia belina worm is a larval stage of mopane worm moth. Its common name mopane is derived from the host plant, Colophospermum mopane (Makhado et al., 2009; Dube and Dube; 2010; Moreki et al., 2012). It is found mainly in developing countries in the southern region of Africa, and widely distributed in South Africa, Namibia, Botswana, Zambia, Angola, Mozambique, Botswana, Zimbabwe, and Malawi (Makhado et al., 2012). Its exoskeleton is tough and covered by black or dark reddish brown spines, which during harvesting cause pain, lacerations, and associated hairs have a slight rusticating effect. In addition, Gondo et al. (2010) indicated that when the larvae are handled, they release a slimy green fluid through their mouth.

During the first three instar stages, the mopane worms are gregarious and forage in groups of 20 to 200 caterpillars (Akpalu et al., 2007), while worms of the remaining two instar stages tend to be solitary (Gondo et al., 2010). At the end of the larval stage, the



Figure 1. Imbrasia belina at different stages of development: (A) worm 5 weeks after hatching, (B) worm 6 weeks after hatching, (C) full grown worm ready to bury itself underground and (D) worm 7 weeks after hatching; scale bar $=6 \mathrm{~cm}$ (Dube and Dube, 2010)

fifth instar caterpillars descend from the tree and burrow $10-15 \mathrm{~cm}$ into the ground where they undergo metamorphosis (Akpalu et al., 2007; Dube and Dube, 2010; Gondo et al., 2010) as shown in Figure 1. The mopane moth is bivoltine throughout the most of its distribution, meaning there are usually two generations each year (Akpalu et al., 2007). Generations of the moth emerge during the summer months when temperatures are typically high, rainfall is most likely to fall and mopane trees are in leaf (Thomas, 2013). Depending on the generation, pupae remain underground for six to seven weeks (first generation) or experience a period of diapause and emerge six to seven months later (Gondo et al., 2010). The life cycle of the first generation of the species for the season begins when adult moths from the previous season mate and lay eggs, usually between October and January, and the first generation of adults then gives rise to the second generation of eggs between February and May (Dube and Dube, 2010) as shown in Figure 2. In the case of bivoltine populations, the first generation tends to be more abundant than the second, but the size of the population for both generations is greatly variable from year to year and is dependent on factors such as food availability and 
rainfall (Thomas, 2013). In some more arid areas, the species are univoltine (Akpalu et al., 2007), so only one emergence of moths occurs each year in summer.

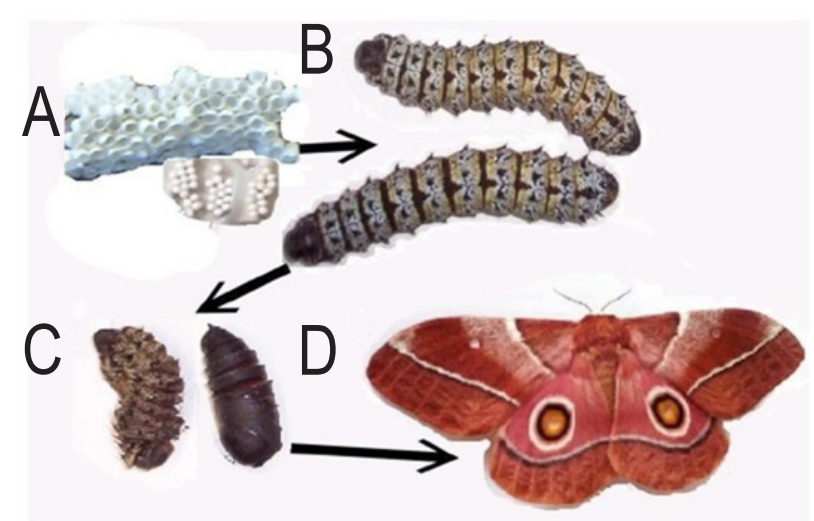

Figure 2. The life cycle of Imbrasia belina: (A) eggs, (B) larva, (C) pupa and (D) adult female (Dube and Dube, 2010)

\section{Availability of I. belina worm}

According to Makhado et al. (2009) and Makhado et al. (2012), I. belina worm prevalence is highly affected by some factors that include prevailing weather conditions, predatory and pressure at harvesting. In addition, rainfall plays a major role in promoting egg-laying by the emperor moth. Erratic, low and irregular rainfalls significantly lower the population of I. belina worms (Lucas, 2010). Hence, climate is a very important factor allowing worms to survive from hatching to pupation; the first generation is mostly affected by adverse weather conditions (Greyling and Potgieter, 2004). Imbrasia belina worm requires ecological harvesting so as to ensure a good crop for the following season (Akpalu et al., 2007). Pitiable harvesting practices of I. belina, due to competition among harvesters, put pressure on mopane worm population leading to decline in in the next generation (Makhado et al., 2009). Furthermore, the various growth stages of the worm life cycle provide food for natural predators (Greyling and Portigieter, 2004), and this predation can have significant impact on I. belina worm yield. As already indicated, the availability of I. belina worm may change due to biotic and abiotic conditions of the environment (Melo et al., 2011). Hence, this implies that availability of $I$. belina worm cannot be guaranteed. As a result, Dube and Phiri (2013) pointed out that there is need to understand the consequences of such factors on worm availability.

In addition, Akpalu et al. (2007) pointed that the first generation tends to be more abundant than the second, though quantities attained have not been noted yet. However, the size of population for both generations is greatly variable year to year, depending on factors like food availability and rainfall. Also, the accessibility of the I. belina worm depends on a tight synchrony of the availability of vegetative material on mopane trees and hatching of the moth eggs. Hence it would be worth discovering the opportunity of breeding mopane worms in confinement and freeing the butterfly to re-seed the mopane foliage when the environments are encouraging (Stack et al., 2003).

\section{Sustainability in harvesting I. belina worms}

When collecting a common, high valued worm from nature, one of the perils is overexploitation, which can threaten forthcoming produce. Overharvesting mainly occurs when there is a food shortage or increase returns from sale. Consequently, in Zimbabwe, concerns in opportunities for small scale farming of I. belina worm arose (Hope et al., 2009). The absence of regulations for the collection of I. belina worm has also increased the competition for harvesting between local people and outsiders at the same time affecting the worm life cycle. Threats linked with harvesting include destroying the mopane trees whereby the trees are chopped down so as to make the worm reachable, incorrect timing and length of the harvesting period, taking too many, under-aged larvae, too many harvesters and adverse environmental impacts linked with harvesters such as trampling, fire wood collection and litter (Thomas, 2013). The use of fire to process the I. belina worm results in patches of veld being burnt, therefore its sequel is reduced grazing capacity of the veld. Nevertheless, traditional regulations may include: monitoring the caterpillar development, abundance, harvesting mature and bigger worms than the younger and smaller ones. Nevertheless, increased demand for mopane worm, apart from traditional control, calls for government legislation and permits to control harvesting (Dube and Dube, 2010). In communal areas regulation may involve harvesting permits that regulate the number of harvesters, the place of collection, the number and size of I. belina worms, and number of days spent on harvesting (Mufandaedza et al., 2015). In addition, government should establish also non-harvest areas as nature reserves, and areas harvested on rotational basis and sacred sites. It is important since the population of the I. belina worms not picked in one period would define abundance in the next period 
(Akpalu et al., 2007). Furthermore, recognition of the property rights may also allow locals to manage and control their own land hence protecting them from outside harvesters.

\section{Mass rearing and breeding of mopane worm}

In most countries, wild harvesting is the most common way to collect the mopane worm. Furthermore, the worm may not be available all year round in the wild due to seasonal and geographical variations. In order to ensure all year-availability of mopane worm, mass rearing is currently being studied in Zimbabwe, South Africa and Botswana (Rapatsa and Moyo, 2017). Hence, the industrial scale worm production, assisted by sustainable worm breeding, farming and processing technologies, can ease the challenges of worm availability and lower the sale price of edible worms (Raheem et al., 2018). According to Gondo et al. (2010), the efforts to farm mopane worms in deliberately planted mopane forests in order to meet the increasing demand have met with varying success. What is more, Gardiner (2003) conducted a project demonstrating that it was possible to establish and maintain a captive breeding population of I. belina for over of three years. In addition, attempts to semi-cultivate and domesticate the mopane caterpillar as a food source has had positive results. However, such issues as susceptibility to viral and bacterial diseases of I. belina worms need to be addressed before their wider utilisation.

\section{Nutritive value of I. belina worm}

\section{Proximate and mineral analysis}

The inclusion level of protein in diets is one of the most crucial principles that needs to be taken into account when talking about feed protein sources (Sánchez-Muros et al., 2014). Studies regarding protein value of $I$. belina indicate that it has high quality and quantity of protein (Dube and Dube, 2010; Moreki et al., 2012; Manyeula et al., 2013) which is comparable with other commonly used protein sources as shown in Table 1. Furthermore, Johnson (2010) and Xiaoming et al. (2010) affirmed that most edible insects are nutritious and provide adequate proteins and other major nutrients needed by poultry and fish.

According to Akpalu et al. (2007), I. belina worm contains higher levels of protein, fat, carbohydrates and minerals than beef and chicken.
Table 1. Chemical composition of Imbrasia belina, fish meal and soybean meal

\begin{tabular}{|c|c|c|c|c|c|c|}
\hline Indices & I. belina & Ref & $\begin{array}{l}\text { Fish } \\
\text { meal }\end{array}$ & Ref & $\begin{array}{l}\text { Soybean } \\
\text { meal }\end{array}$ & Ref \\
\hline \multicolumn{7}{|c|}{ Nutrient, \% } \\
\hline $\mathrm{CP}$ & $54-59$ & $b, c, e, f$ & 65.5 & $d$ & $40.1-46.8$ & $a, d$ \\
\hline ash & $6.9-10.4$ & $b, c, e, f$ & 18.0 & $d$ & 6.13 & $d$ \\
\hline NDF & 27.8 & a & $\mathrm{N} / \mathrm{D}$ & - & 14.5 & $d$ \\
\hline ADF & $16-58.4$ & $b, e, f$ & $\mathrm{~N} / \mathrm{D}$ & - & 9.5 & $d$ \\
\hline$A D L$ & 5.2 & $b$ & $\mathrm{~N} / \mathrm{D}$ & - & $N / D$ & - \\
\hline ADIN & 0.9 & $b$ & $\mathrm{~N} / \mathrm{D}$ & - & N/D & - \\
\hline fat & $12.9-16.7$ & $b, c, e, f$ & 12.0 & $d$ & $18.2-20$ & $a, d$ \\
\hline \multicolumn{7}{|c|}{ Minerals, mg/g } \\
\hline K & $1.1-35.2$ & $b, e, f$ & 0.5 & $d$ & 19.85 & $d$ \\
\hline $\mathrm{Ca}$ & $0.7-16$ & $b, e, f$ & 3.9 & $d$ & 3.12 & $d$ \\
\hline$P$ & $0.45-14.7$ & $b, e, f$ & 2.6 & $d$ & 6.64 & $d$ \\
\hline $\mathrm{Mg}$ & $4.1-54$ & $b, e, f$ & 0.0 & $d$ & 2.72 & $d$ \\
\hline $\mathrm{Fe}$ & $11.6-12.7$ & $b, e, f$ & 0.2 & $d$ & N/D & - \\
\hline $\mathrm{Zn}$ & $1.9-2.1$ & $b, e, f$ & 0.0 & $d$ & N/D & - \\
\hline $\mathrm{Na}$ & $26.7-33.3$ & $b, e, f$ & 0.8 & $d$ & $0.18-04$ & $a, d$ \\
\hline
\end{tabular}

References: a-da Silva etal. (2009), b-Madibela etal. (2009), c-Dube and Dube (2010), d-Gümüş (2011), e-Morekietal. (2012), f-Manyeula et al. (2013); ND - not detected; CP - crude protein; NDF - neutral detergent fibre; ADF - acid detergent fibre; ADL - acid detergent lignin; ADIN - acid detergent insoluble nitrogen

In addition, Madibela et al. (2007) estimated that it contains $50 \%$ crude protein (CP). This could be attributed to the fact that mopane leaves (leaves on which I. belina feeds) are characterised by the high value of CP (Wessels et al., 2007). Furthermore, according to Madibela et al. (2009) removal of the gut content improves the $\mathrm{CP}$ concentration of the I. belina worm by $10 \%$. This is because the gut content consists of plant material which is mainly built of carbohydrates. As a result, removal of carbohydrate rich content of the gut results in a relatively larger amount of the remaining constituent protein and fat (Lautenschläger et al., 2017). This could be attributed to the fact that tannins in the gut content can lower the level of available protein by antagonistic competition (Ekop, 2009). The mineral profile of I. belina depends to a large extent on its diet (Henry et al., 2015). Whilst Rapatsa and Moyo (2017) revealed that minerals in I. belina worm were much higher than those in fish meal (the phosphorous as the one exception). Despite the fact that calcium and phosphorus are required as structural components of the skeleton (McDonald et al., 2002). The I. belina worm meal is rich in sodium attributed by addition of salt during processing. Also high levels of iron were reported in these worms, which may be connected with the alkaline soils, rich in iron, on which mopane trees are usually found (Stack et al., 2003). 
In a study by Rapatsa and Moyo (2017), acid detergent fibre (ADF) was taken as a surrogate measure of chitin. The increased growth performance of Mozambique tilapia (Oreochromis mossambicus) with higher I. belina worm inclusion levels suggests that chitin did not affect nutrient digestibility. Chitin is not hydrolysed in the intestinal tract of most fish due to the absence of chitinase, hence making it possible for I. belina worm to be utilised as fish meal (Rapatsa and Moyo, 2017). According to Madibela et al. (2013) concentration levels of CP was reduced by $9 \%$ in a study determining the suitability of I. belina worm as feed. Whereas, in an earlier study Madibela et al. (2009) noted an increase in the $\mathrm{ADF}$, neutral detergent fibre (NDF) and lignin in degutted I. belina worm samples. Hence, Madibela et al. (2013) pointed that this could reflect that gut content of I. belina worm neutralises the CP content, while increases the concentration of lignin, ADF and NDF.

\section{Amino acids}

Livestock, particularly poultry and fish, do not have true protein requirements, but rather amino acid (parts of protein) needs (Teles et al., 2011). Hence, protein quality depends on the amino acid composition - mainly the balance among dispensable and indispensable amino acids is important (Sánchez-Muros et al., 2014). Amino acids are very crucial components in broiler diets, improper intake can cause detrimental effects on growth and production (Kim, 2010). Also, they play an imperative role in enzyme and tissue functioning (Li et al., 2011). Imbrasia belina worm contains greater concentrations of some indispensable amino acids, such as threonine, valine, tryptophan and phenylalanine than fish meal and soybean (Mojeremane and Lumbile, 2005). Thus its inclusion into the diet may balance the indispensable amino acids level. In addition, Nobo et al. (2012a) confirmed that levels of some essential amino acids like lysine and methionine in I. belina worm are comparable to fish meal. Whereas, according to Rapatsa and Moyo (2017) the levels of methionine in I. belina exceeded the catfish requirements. Furthermore, Rapatsa and Moyo (2017), pointed that I. belina worm is composed of all essential amino acids (Table 2) required by $O$. mossambicus and poultry. So, it can be utilised to be included into diet and/or substitute fish and soybean meal. This fact could reduce the usage of fish meal and soybean meal in the livestock diets,
Table 2. Amino acid in mopane worm (Imbrasia belina), fish meal and soybean meal

\begin{tabular}{lllllll}
\hline Amino acid & I. belina & Ref & $\begin{array}{l}\text { Fish } \\
\text { meal }\end{array}$ & Ref & $\begin{array}{l}\text { Soybean } \\
\text { meal }\end{array}$ & Ref \\
\hline Methionine & $1.5-2.2$ & a, b, e & $1.5-2.26$ & a, d & $0.54-0.8$ & a, d \\
Lysine & $3.6-4.7$ & a, b, e & $4.8-10.96$ & a, d & $2.85-3.0$ & a, d \\
Tryptophan & $0.7-1.1$ & a, c, e & $0.7-0.97$ & a, d & $0.6-0.64$ & a, d \\
Arginine & 3.2 & a & $3.82-4.2$ & a, d & 3.39 & d \\
Tyrosine & 3.6 & a & 4.6 & a & N/D & - \\
Histidine & $1.7-2.9$ & a, b, e & $1.4-4.19$ & a, d & $1.3-1.19$ & a, d \\
Threonine & $2.7-7.3$ & a, b, e & $2.5-5.28$ & a, d & $1.78-1.9$ & a, d \\
Isoleucine & $2.2-3.0$ & a, b, e & $2.60-2.66$ & a, d & $2.0-2.03$ & a, d \\
Leucine & $3.5-7.1$ & a, b, e & $4.5-8.31$ & a, d & $3.49-3.5$ & a, d \\
Phenylalanine $2.5-5.1$ & a, b, e & $2.9-5.52$ & a, d & $2.22-2.3$ & a, d \\
Valine & $3.2-4.1$ & a, b, e & $3.22-3.1$ & a, d & $2.02-2.2$ & a, d \\
\hline
\end{tabular}

References: a - McDonald et al. (2002), b - Lucas (2010), c- Harlıoglu (2012), d-Rapatsa and Moyo (2017), e - Lautenschläger et al. (2017); ND - not detected

thereby causing the decrease in the price of fish and soybean meal. However, more research needs to be carried out on I. belina worm meal as an ingredient of poultry and fish diets.

\section{Lipids and fatty acids}

Feed rich in protein include some amount of lipids; hence determination of fatty acid composition of lipid is very crucial. This is because lipid contributions can meet the requirements of essential fatty acids or limit the biological function of fatty acids (Sánchez Muros et al., 2014). The ratio of total unsaturated fatty acid to total saturated fatty acid in I. belina was 54:49 with $\alpha$-linoleic acid being the most abundant (Table 3). However, the worm lacked eicosapentaenoic acid (EPA) (C20:5n3) and docosahexaenoic acid (DHA) (C22:6n3), while fresh water fish like $O$. mossambicus requires polyunsaturated fatty acids (PUFA) in their diets (Tocher, 2010). In addition, EPA and DHA are sources of omega-3 fats in poultry diets (Cherian, 2015). Furthermore, Yeboah and Mitei (2009) reported that I. belina worm contains high levels of dietary $\alpha$-linolenic and palmitic acids, which can be helpful to cure alleviating coronary heart disease and chronic ailments. Pharithi et al. (2004) reported that the I. belina worm and the mopane tree, from which it feeds on, have the same fatty acid profile. There is little information on lipid and essential fatty acid requirements for $O$. mossambicus, guinea fowl and broilers. Hence, I. belina worm meal appears to be a suitable lipid source to provide essential fatty acid. Dietary fat levels of I. belina worm meal are not significantly different than that in fish meal (Table 1). 
Table 3. Fatty acid composition (g/100 g) of mopane worm (Imbrasia belina), fish meal and soybean meal

\begin{tabular}{|c|c|c|c|c|c|c|}
\hline Fatty acids & I. belin & Ref & $\begin{array}{l}\text { Fish } \\
\text { meal }\end{array}$ & Ref & $\begin{array}{l}\text { Soybean } \\
\text { meal }\end{array}$ & Ref \\
\hline $\begin{array}{l}\text { Total polyunsatu- } \\
\text { rated fatty acids } \\
\text { (PUFA) }\end{array}$ & 54 & $\mathrm{C}$ & 39.19 & $b$ & $27.96-46.32$ & $a, b$ \\
\hline $\begin{array}{l}\text { Total monounsatu- } \\
\text { rated fatty acids }\end{array}$ & -1.7 & c & $18.55-44.98$ & $b, d$ & $8.45-45.43$ & $a, b, d$ \\
\hline $\begin{array}{l}\text { Total saturated } \\
\text { fatty acids }\end{array}$ & 49 & C & $40.17-52.43$ & $b, d$ & $4.10-53.00$ & $a, b, d$ \\
\hline n-3PUFA & $N / D$ & - & 36.54 & $b$ & 0.77 & $b$ \\
\hline n-6PUFA & $\mathrm{N} / \mathrm{D}$ & - & 2.65 & $\mathrm{~b}$ & 45.55 & $b$ \\
\hline$n-3 / n-6$ & $\mathrm{~N} / \mathrm{D}$ & - & 13.78 & $b$ & 0.14 & $b$ \\
\hline $\begin{array}{l}\text { Lauric acid } \\
\text { C12:0 }\end{array}$ & $<0.1$ & C & $0.11-0.19$ & $b, d$ & 0.18 & e \\
\hline $\begin{array}{l}\text { Myristic acid } \\
\text { C14:0 }\end{array}$ & $<0.1$ & c & $2.77-4.48$ & $b, d$ & $0.21-3.89$ & $a, b, d$ \\
\hline $\begin{array}{l}\text { Palmitic acid } \\
\text { C16:0 }\end{array}$ & 3.2 & c & $27.28-27.48$ & $b, d$ & $12.31-27.32$ & $a, b, d$ \\
\hline $\begin{array}{l}\text { Stearic acid } \\
\text { C18:0 }\end{array}$ & 1.7 & C & $21.86-7.28$ & $c, d$ & $3.74-21.18$ & $a, b, d$ \\
\hline $\begin{array}{l}\text { Arachidic acid } \\
\text { C20:0 }\end{array}$ & $<0.1$ & c & $N / D$ & - & 0.04 & a \\
\hline $\begin{array}{l}\text { Palmitelaidic } \\
\text { C16:1 }\end{array}$ & 0.1 & C & 0.41 & b 1 & $\mathrm{~N} / \mathrm{D}$ & - \\
\hline $\begin{array}{l}\text { Elaidic acid } \\
\text { C18:1n9c }\end{array}$ & 1.6 & c & $N / D$ & - & $\mathrm{N} / \mathrm{D}$ & - \\
\hline $\begin{array}{l}\text { Linolelaidic acid } \\
\text { C18:3 }\end{array}$ & 3.7 & c & $N / D$ & - & $\mathrm{N} / \mathrm{D}$ & - \\
\hline $\begin{array}{l}\text { a-Linoleinic acid } \\
\text { C18:2n6c }\end{array}$ & $<0.1$ & c & $N / D$ & - & $0.72-2.16$ & $a, b$ \\
\hline $\begin{array}{l}\text { Arachidonic acid } \\
\text { C20:4 }\end{array}$ & $<0.1$ & c & $\mathrm{N} / \mathrm{D}$ & - & $\mathrm{N} / \mathrm{D}$ & - \\
\hline Linoleic C18:2 & 1.6 & - & 2.57 & $d$ & $1.55-11.6$ & $a, b, d$ \\
\hline $\begin{array}{l}\text { Oleic acid } \\
\text { C18:1n9c }\end{array}$ & 1.6 & - & 44.98 & d & 45.43 & $d$ \\
\hline
\end{tabular}

References: a - van Eys et al. (2004), b - Gümüş (2011), c - Rapatsa and Moyo (2017), d - Romero-Bernal et al. (2017); ND - not detected

\section{Indigestibility components of I. belina worm}

\section{Chitin and strategies of overcoming it}

Chitin is a polysaccharide present or found in the exoskeleton of arthropods. It is a polymer of $\beta(1 \rightarrow 4)$ joined by a $\beta(1 \rightarrow 4)$ glycosidic bond, a crude fibre (Lindsay et al., 1984) that is not digestible by monogastric animals. Furthermore, Kwiri et al. (2014) reported that $27 \%$ of I. belina dry weight is chitin, an exoskeleton component. Chitin impedes protein utilisation (Longvah et al., 2011) as it evades the access of digestive enzyme to hydrolyse protein, lipids, fat-soluble vitamins and minerals thus affecting their utilisation (Mahata et al., 2008). Nevertheless, its removal increases the net protein utilisation (NPU), improves the value of insect protein as some proteins are connected to it
(Rumpold and Schuler, 2013). This fact should be taken into account when processing I. belina worm. Belluco et al. (2013) pointed out that elimination of chitin raises the value of insect protein to the level of vertebrate animal protein. However, this may lead to the additional costs connected with processing and removing chitin.

\section{Species fed diets containing I. belina worm meal}

\section{Poultry}

The main challenge in the poultry industry is to avail feeds containing all indispensable diet constituents for the birds to promptly mature (Oyegoke et al., 2006). What is more, the nutritive needs of monogastric species, particularly, broilers, layers, and guinea fowls include a high value and quantity of protein in the diet. From a nutritional point of view, protein sources must be characterised by a high-protein content with adequate amino acid profiles, high digestibility and good palatability (Barrows et al., 2008). Imbrasia belina worm was shown to possess most of the mentioned protein qualities.

According to Nobo et al. (2012b) guinea fowls fed a diet containing $4.5 \%$ of the $I$. belina worm had a higher feed intake compared to those fed a diet with a $13.5 \%$ additive and a control one. This could be due to the speculation that chitin in I. belina may influence the apparent digestibility coefficient of the total tract nutrient (De Marco et al., 2015) and render feed unpalatable and indigestible. In addition, as the energy in the diet increases, the feed intake decreases (Veldkamp et al., 2005). This is because the increase of dietary energy level improves feed conversion ratio, hence reducing feed intake (Dozier et al., 2006; Ghaffari et al., 2007). As a result, the increase in the diet levels does not contribute to the good performance of the guinea fowl. However, guinea fowl fed higher levels of I. belina worm diet had lower body weight during the study than other treatments. It shows that higher levels of I. belina worm have deleterious effects on guinea fowl growth performance, especially at its early stages of growth.

Furthermore, Mareko et al. (2010) revealed that weight of broilers fed $20 \%$ I. belina worm was significantly different in comparison with the control. At 6 weeks of age, control birds weighted $2.016 \pm 0.042 \mathrm{~kg}$ whereas those fed I. belina worm $1.480 \pm 0.042 \mathrm{~kg}$. This is in agreement with the 
findings of Nsoso et al. (2006) who observed that broilers under commercial feeding at 6 weeks of age should weigh $2 \mathrm{~kg}$. This could be attributed to the supplement characteristics, which fed at higher levels becomes unpalatable and as a consequence limits the feed intake. Nsoso et al. (2008) and Mareko et al. (2010) also stated that higher levels of I. belina worm render it unpalatability and hence its intake was lower in guinea fowl. Later, Nobo et al. (2012b) suggested that I. belina worm meal can be fed to guinea fowl at $4.5 \%$ without negative effects on growth performance. Nonetheless, further findings need to be done in order to determine inclusion levels at which the I. belina worm meal can be fed to guinea fowl without significant affection of weight gains. Mareko et al. (2010) revealed that sodium content in meat was higher in birds fed I. belina worm meal at inclusion of 20 to $40 \%$ in comparison to control group; however meat sodium level was still lower than that found by Nsoso et al. (2008). This variation may be attributed to different species raised under different housing systems and feed types. Furthermore, Mareko et al. (2010) stated significant amounts of phosphorous in meat of birds fed diet supplemented with $40 \%$ of I. belina worm or the control one.

Mareko et al. (2008) also revealed 0.72-0.92\% of potassium content in meat of animals fed I. belina, whereas Mareko et al. (2010) recorded 1.52-1.57\%. Potassium and sodium are very crucial minerals in osmotic regulation of the body fluids and an acid base-balance in animals. They also play a pivotal role in nerve and muscle excitability and in carbohydrate metabolism (Choi and Ha, 2013).

Furthermore, Manyeula et al. (2013) noted that layer chickens fed $18 \%$ I. belina worm meal had high average daily gains (ADG) $(4.77 \mathrm{~g})$ and low feed conversion ratio (FCR) $(1.10 \pm 0.16)$ (Table 4). Low FCR in hens fed I. belina worm diet could be attributed to lower feed intake due to possible unpalatability and indigestibility of the feed.

Table 4. Growth and laying performance of Tswana hens fed on three protein sources (Tylosema esculentum, Vigna subterranean and Imbrasia belina) from 25-38 week of age (according to Manyeula et al., 2013)

\begin{tabular}{|c|c|c|c|c|}
\hline Parameters & Control & T. esculentum & V.subterranear & I. belina \\
\hline $\mathrm{Fl}, \mathrm{g}$ & $84.6 \pm 7.9^{a}$ & $54.9 \pm 7.9^{b}$ & $59.3 \pm 7.9^{b}$ & $59.6 \pm 7.9^{b}$ \\
\hline FCR & $1.76 \pm 0.16^{b}$ & $1.61 \pm 0.16^{b}$ & $1.23 \pm 0.16^{a}$ & $1.10 \pm 0.16^{a}$ \\
\hline$A D G, g / d$ & $3.27 \pm 1.16^{a}$ & $0.82 \pm 1.60^{b}$ & $3.13 \pm 1.51^{\mathrm{a}}$ & $4.77 \pm 1.31^{a}$ \\
\hline HDEP, $\%$ & $90 \pm 0.87^{a}$ & $41 \pm 0.87^{d}$ & $67 \pm 0.87^{c}$ & $75 \pm 0.87^{b}$ \\
\hline
\end{tabular}

FI - feed intake per hen per day; FCR - feed conversion ratio; ADG - average daily gain per hen; HDEP - hen day egg production; abcd - means with different superscript in the same row are significantly different at $P<0.05$
The findings also indicate that low FCR could result in increased weight gain from consumption of little feed of good quality (Haryanto et al., 2016). Hence, less consumed feed reduces the cost of production. Madibela et al. (2006) reported that I. belina worm meal is superior in essential amino acids content compared to soybean and fish meal. Furthermore, Nobo et al. (2012a) reported no significant differences in feed intake, ADG, FCR and dressing percentage between guinea fowl fed fish meal (control diet) and $4.5 \%$ I. belina worm meal. The differences in Manyeula et al. (2013) and Nobo et al. (2012a) studies could be ascribed to the used Tswana birds and guinea fowls and their sex differences. Layers fed I. belina worm and control diet produced 11 and 14 eggs/clutch/year, respectively. These findings are in agreement with the study of Moreki et al. (2010). In addition, a hen day egg production (HDEP) from those animals fed I. belina worm was $75 \pm 0.87$ (Manyeula et al., 2013). This could be attributed to the fact that I. belina worm contains adequate amounts of amino acids and minerals like phosphorus and calcium to support egg production, however other essential ingredients could have contributed to it as well.

In the study of Chiripasi et al. (2013) it was revealed that guinea fowl birds fed $4.5 \%$ I. belina worm diet had lower bone width in comparison to other treatment diets. In addition, bone width in birds fed control diet, 9 and $13 \%$ I. belina worm meal did not significantly differ. Furthermore, bone weights were negatively influenced by $9 \%$ I. belina worm meal. Therefore, it is suggested that the diet containing $4.5 \%$ I. belina worm meal promoted more bone mineral deposition resulting in heavier weights than the other treatment diets. Furthermore, Chiripasi et al. (2013) reported that guinea fowls fed $4.5 \%$ I. belina were characterised by higher bone mineral composition of phosphorus $(3536.2 \mathrm{mg} / \mathrm{l})$, sodium (1332.96 mg/l) and potassium (1841 mg/l) than those fed control, 9 and $13.5 \%$ inclusions. Higher bone mineralisation is recorded at lower I. belina inclusion levels because increase in inclusion levels render the feed unpalatability and indigestibility (Madibela et al., 2007) leading to reduced feed intake and bone mineralisation. In addition, bones of birds fed $13.5 \%$ I. belina worm meal diet had the lowest copper content, whereas 4.5 and $9 \%$ inclusion levels did not influence this indicator significantly. This finding is supported by the estimation that copper level in I. belina is 8-12 mg/l (Pillay, 2015). Therefore, increasing inclusion levels of I. belina in the diet results in low levels of copper consumed by the bird. 
Furthermore, according to Chiripasi et al. (2013) the content of magnesium in bones of birds fed control, 9 and $13.5 \%$ I. belina meal diets did not significantly differ and amounted 655.82-658.84 mg/l. On the other hand, the content of iron in bones was the highest in birds fed $13.5 \%$ I. belina worm meal $(204.64 \mathrm{mg} / \mathrm{l})$ and this is inconsistent with Moreki et al. (2011) who reported that the content of iron in bones amounted $95.07 \mathrm{mg} / \mathrm{l}$. These findings could be related to the relatively high daily mineral intakes of 0.1577 to $0.2347 \mathrm{~g} /$ day and also the high levels of iron present in mopane tree leaves (Pillay, 2015). Furthermore, it was revealed that in guinea fowls fed 4.5, 9 and $13.5 \%$ of I. belina worm meal bone mineral composition was almost the same. Therefore, it could be stated that increasing I. belina worm meal concentration to $13.5 \%$ do not lead to better bone mineralisation. Even $4.5 \%$ inclusion could be enough to maintain possible optimum level for bone mineralisation. Chitin present in I. belina worm meal makes it highly unpalatable and poorly digestible (Madibela et al., 2007), and as a result leads to reduced feed intake and reduced bone mineralization especially at $13.5 \%$ inclusion. McDonald et al. (2002) alluded that calcium, potassium and magnesium are required as structural components of the skeleton and these components were found in high concentration in a study by Chiripasi et al. (2013). Also, these authors observed that I. belina worm meal can replace fish meal by up to $9 \%$ without affecting mineral intake, retention and utilisation. Inclusion of I. belina worm into poultry diets caused various results of bone mineralisation and bone width, therefore the effect of I. belina worm meal intake on poultry bone density and strength needs to be studied in detail.

Furthermore, in the study of Chiripasi et al. (2013) it was shown that meat from guinea fowl fed diet containing $4.5 \%$ of $I$. belina worm meal was characterised by significantly higher calcium content than 9 and $13.5 \%$ I. belina worm inclusions and control diet. The calcium mean value $(10.29 \mathrm{mg} / 100 \mathrm{~g})$ obtained by Chiripasi et al. (2013) corresponded to the value of $15.87 \mathrm{mg} / 100 \mathrm{~g}$ obtained by Thong (2008). These differences may be due to the differences in treatment diets used in both studies and animals used. Mareko et al. (2008), reported calcium and phosphorus values ranging from 0.14 to $0.16 \%$ and 1.81 to $2.55 \%$, respectively. Hence calcium content in guinea fowl meat was lower than in the bone. It has been observed that I. belina worm meal inclusion into poultry diet influenced bone mineralisation and meat characteristics. So, it is necessary to study its impact on egg quality (shell strength, egg composition and yolk colour) when fed to poultry layers.

\section{Fish}

Utilised widely, fish meal is highly valuable for aquaculture and, as a result, it is becoming gradually rare and expensive. Increasing fish meal prices promoted the use of low inclusion levels; however, it is counterbalanced by the fast development of aquaculture sector (Olsen and Hasan, 2012; World Bank et al., 2013). Such situation promotes the exploration of substitute sources, for example the use of I. belina worm meal.

Rapatsa and Moyo (2017) noted a significant difference in growth parameters of $O$. mossambicus fed different levels of I. belina worm diets. The best growth rate performance was observed in control animals, however the specific growth rate (SGR), thermal unit growth coefficient (TGC), and apparent digestibility coefficient were increased at $60 \%$ I. belina worm inclusion level. However, this report differs from other studies where growth performance was declined with higher inclusion levels of the test ingredient (Sánchez-Muros et al., 2014). This is also inconsistent with the findings of Mwimanz and Musuka (2014) indicating not impressive results under $50 \%$ inclusion level. This could be attributed to the observation that I. belina worm is possibly rich in other anti-nutritional factors like condensed tannins and phenols (Wessels et al., 2007) other than chitin. It may be also stated that the amino acid profile of I. belina worm was not appropriate for Oreochromis macrochir at that inclusion level. However, according to Mwimanz and Musuka (2014) there are no studies conducted on the amino acids requirements of $O$. macrochir hence there is a need to conduct such. Interestingly the inclusion levels of 50,75 and $100 \%$ used by Mwimanz and Musuka (2014) are already too high in comparison to Rapatsa and Moyo (2017). Anyway, more detailed research connected with I. belina worm that possibly could replace fish meals is needed.

\section{Conclusions and future perspective}

Imbrasia belina worm is a potential and equal protein substitute, which can be utilised in livestock feed preparations. It is known to be a source of animal protein, fat, minerals, fatty acids and amino acids, which contribute greatly to the growth performance of fish, broilers and guinea fowls. It is well documented that it can be utilised for animal feed, 
when compared with the control. Furthermore, this review revealed that $I$. belina lacks polyunsaturated omega-3 fatty acids, eiocosapentaenoic acid (EPA) and docosahexaenoic acid (DHA) in its fatty acid profile. There is need, of course, for further possibilities of using I. belina worm as a substitute to fish meal and fish oil in poultry and fish meal. However, this worm is overexploited during harvesting, hence there is a need to enforce traditional and government regulations so as to sustainable harvest I. belina worm.

Despite positive outcomes on the potential use of $I$. belina worm as poultry and fish diets to increase their performance and product quality there is yet a challenge of chitin that could limit the inclusion level. However further research on the enzyme additives (chitinase) to enrich I. belina worm should be considered in order to increase the inclusion level of I. belina worm meal and to improve nutrient digestibility. Currently, the chitin content and digestibility seem to prevent the inclusion of I. belina in poultry diet at levels higher than 20-30\%. Research focusing on the nutritional composition of I. belina worm instar growth stages and the worm without exoskeleton would be of paramount importance. Imbrasia belina worm has been consumed by human beings, poultry and fish, therefore research focusing on its effect on ruminants would be interesting as no or little has been reported till now. Despite I. belina nutritional properties, its effect on broiler meat quality has not been determined.

\section{References}

Akpalu W., Muchapondwa E., Zikhali P., 2007. Can the restrictive harvest period policy conserve mopane worms in Southern Africa? A bio-economic modeling approach. Working Paper Number 65. University of Pretoria/University of Cape Town/ GItenborg University (South Africa), https://efdinitiative.org/ sites/default/files/wp65.pdf

Barrows F.T., Bellis D., Krogdahl Å., Silverstein J.T., Herman E.M., Sealey W.M., Rust M.B., Gatlin III D.M., 2008. Report of the plant products in aquafeed strategic planning workshop: an integrated, interdisciplinary research roadmap for increasing utilisation of plants feedstuffs in diets for carnivorous fish. Rev. Fish. Sci. 16, 449-455, https://doi. org/10.1080/10641260802046734

Belluco S., Losasso C., Maggioletti M., Alonzi C.C., Paoletti M.G., Ricci A., 2013. Edible insects in a food safety and nutritional perspective: a critical review. Compr. Rev. Food Sci. Food Saf. 12, 296-313, https://doi.org/10.1111/1541-4337.12014

Cherian G., 2015. Nutrition and metabolism in poultry: role of lipids in early diet. J. Anim. Sci. Biotechnol. 6, 28, https://doi. org/10.1186/s40104-015-0029-9

Chiripasi S.C., Moreki J.C., Nsoso S.J., Letso M., 2013. Effect of feeding mopane worm meal on mineral intake, retention and utilisation in Guinea fowl under intensive system. Int. J. Poult. Sci. 12, 19-28, https://doi.org/10.3923/ijps.2013.19.28
Choi H.Y., Ha S.K., 2013. Potassium balances in maintenance hemodialysis. Electrolyte. Blood Press. 11, 9-16, https://doi. org/10.5049/EBP.2013.11.1.9

da Silva J.B., Carrão-Panizzi M.C., Prudâncio S.H., 2009. Chemical and physical composition of grain-type and food-type soybean for food processing. Pesqui. Agropecu. Bras. 44, 777-784, https://doi.org/10.1590/S0100-204X2009000700019

De Marco M., Martínez S., Hernandez F. et al., 2015. Nutritional value of two insect larval meals (Tenebrio molitor and Hermetia illucens) for broiler chickens: Apparent nutrient digestibility, apparent ileal amino acid digestibility and apparent metabolizable energy. Anim. Feed Sci. Technol. 209, 211-218, https:/l doi.org/10.1016/j.anifeedsci.2015.08.006

Dozier III W.A., Price C.J., Kidd M.T., Corzo A., Anderson J., Branton S.L., 2006. Growth performance, meat yield, and economic responses of broilers fed diets varying in metabolizable energy from thirty to fifty-nine days of age. J. Appl. Poult. Res. 15, 367-382, https://doi.org/10.1093/japr/15.3.367

Dube S., Dube C., 2010. Towards improved utilisation of macimbi Imbrasia belina Linnaeus, 1758 as food and financial resource for people in the Gwanda district of Zimbabwe. J. Sci. Tech. $5,28-36$

Dube T., Phiri K., 2013. Rural livelihoods under stress: the impact of climate change on livelihoods in South Western Zimbabwe. Am. Int. J. Contemp. Res. 3, 11-25

Ekop A.S., 2009. Changes in amino acid composition of African yam beans (Sphenostylis stenocarpas) and African locust beans (Parkia filicoida) on cooking. Pak. J. Nutr. 5, 254-256, https:// doi.org/10.3923/pjn.2006.254.256

FAO Committee on Fisheries, 2012. Report of the sixth session of the Sub-Committee on Aquaculture. 26-30 March 2012, Cape Town, South Africa. FAO. Rome (Italy), pp. 26-30, http://www. fao.org/docrep/016/i2765t/i2765t.pdf

Garcia M.A., Altieri M.A., 2005. Transgenic crops: implications for biodiversity and sustainable agriculture. Bull. Sci. Technol. Soc. 25, 335-353, https://doi.org/10.1177/0270467605277293

Gardiner A.J., 2003. Internal Final Report: Mopane Woodlands and the Mopane Worm: Enhancing Rural Livelihoods and Resource Sustainability, DFID Project No. R7822. The Domestication of Mopane Worms (Imbrasia belina). Veld Products Research \& Development, Gaborone (Botswana)

Ghaffari M., Shivazad M., Zaghari M., Taherkhani R., 2007. Effect of different levels of metabolizable energy and formulation of diet based on digestible and total amino acid requirements on performance of male broiler. Int. J. Poult. Sci. 6, 276-279, https://doi.org/10.3923/ijps.2007.276.279

Gondo T., Frost P., Kozanayi W., Stack J., Mushongahande M., 2010. Linking knowledge and practice: assessing options for sustainable use of mopane worms (Imbrasia belina) in Southern Zimbabwe. J. Sustain. Dev. Afr. 12, 281-305

Greyling M., Potgieter M., 2004. Mopane worms as key woodland resource. The use trade and conservation of Imbrasia belina. In: M.J. Lawes, H.A.C. Ealey, C.M. Shackleton, B.G.S. Geach (Editors). Indigenous Forests and Woodlands in South Africa: Policy, People and Practice. University of KwaZulu-Natal Press. Pietermaritzburg (South Africa), pp. 575-589

Gümüş E., 2011. Fatty acid composition of fry mirror carp (Cyprinus carpio) fed graded levels of sand smelt (Atherina boyeri) meal. Asian-Australas. J. Anim. Sci. 24, 264-271, https://doi. org/10.5713/ajas.2011.10223

Harlıoğlu A.G., 2012. Effect of solvent extracted soybean meal and full-fat soya on the protein and amino acid digestibility and body amino acid composition in rainbow trout (Oncorhynchus mykiss). Iran. J. Fish. Sci. 11, 504-517 
Haryanto A., Miharja K., Wijayanti N., 2016. Effects of banana peel meal on the feed conversion ratio and blood lipid profile of broiler chickens. Int. J. Poult. Sci. 15, 27-34, https://doi. org/10.3923/ijps.2016.27.34

Henry M., Gasco L., Piccolo G., Fountoulaki E., 2015. Review on the use of insects in the diet of farmed fish: past and future. Anim. Feed. Sci. Technol. 203, 1-22, https://doi. org/10.1016/j.anifeedsci.2015.03.001

Hope R.A., Frost P.G.H., Gardiner A., Ghazoul J., 2009. Experimental analysis of adoption of domestic mopane worm farming technology in Zimbabwe. Dev. South. Afr. 26, 29-46, https:// doi.org/10.1080/03768350802640065

International Monetary Fund, 2010. International Monetary Fund Primary Commodity Prices, http://www.imf.org/external/ data.htm

Johnson D.V., 2010. The contribution of edible forest insects to human nutrition and to forest management: current status and future potential. In: P.B. Durst, D.V. Johnson, R.N. Leslie, K. Shono (Editors). Forest Insects as Food: Humans Bite back. Proceedings of a workshop on Asia-Pacific resources and their potential for development. 19-21 February 2008. Chiang Mai, Thailand. FAO Regional Office for Asia and the Pacific. Bangkok (Thailand), pp. 5-22

Kim E.J., 2010. Amino acid digestibility of various feedstuffs using different methods. PhD Dissertation. University of Illinois. Urbana, IL (USA)

Kwiri R., Winini C., Muredzi P., Tongonya J., Gwala W., Mujuru F., Gwala S.T., 2014. Mopane worm (Gonimbrasia belina) utilisation, a potential source of protein in fortified blended foods in Zimbabwe. A review. Glob. J. Sci. Front. Res. D Agric. Vet. 14, 55-67

Lautenschläger T., Neinhuis C., Kikongo E., Henle T., Förster A., 2017. Impact of different preparations on the nutritional value of the edible caterpillar Imbrasia epimethea from northern Angola. Eur Food Res. Technol. 243, 769-778, https://doi.org/10.1007/s00217-016-2791-0

Li X., Rezaei R., Li P., Wu G., 2011. Composition of amino acids in feed ingredients for animal diets. Amino Acids 40, 11591168, https://doi.org/10.1007/s00726-010-0740-y

Lindsay G.J.H., Walton M.J., Adron J.W., Fletcher T.C., Cho C.Y., Cowet C.B., 1984. The growth of rainbow trout (Salmo gairdneri) given diets containing chitin and its relationship to chitinolytic enzymes and chitin digestibility. Aquaculture 37, 315-334, https://doi.org/10.1016/0044-8486(84)90297-7

Longvah T., Mangthya K., Ramulu P., 2011. Nutrient composition and protein quality evaluation of eri silkworm (Samia ricinii) prepupae and pupae. Food Chem. 128, 400-403, https:// doi.org/10.1016/j.foodchem.2011.03.041

Lucas L.T., 2010. The evolution and impacts of mopane worm harvesting: Perceptions of harvesting in central Botswana. Master of Science Degree. University of the Witwatersrand, Johannesburg (South Africa)

Madibela O.R., Giddie B., Mokwena K.K., 2013. Dry matter and crude protein degradability of mopane worm (Imbrasia belina) in rumen of steers. Iran. J. Appl. Anim. Sci. 3, 39-43

Madibela O.R., Mokwena K.K., Nsoso S.J., Thema T.F., 2009. Chemical composition of Mopane worm sampled at three sites in Botswana and subjected to different processing. Trop. Anim. Health. Prod. 41, 935-942, https://doi. org/10.1007/s11250-008-9282-7

Madibela O.R., Seitiso T.K., Thema T.F., Letso M., 2007. Effect of traditional processing methods on chemical composition and in vitro true dry matter digestibility of Mophane worm (Imbrasia belina). J. Arid Environ. 68, 492-500, https://doi. org/10.1016/j.jaridenv.2006.06.002
Madibela O.R., Seitshiro O., Mochankana M.E., 2006. Deactivation effects of polyethylene glycol (PEG) on in vitro dry matter digestibility of Colophospermum mopane (Mophane) and acacia browse trees in Botswana. Pak. J. Nutr. 5, 343-347, https://doi.org/10.3923/pjn.2006.343.347

Mahata M.E., Dharma A., Ryanto H.I., Rizal Y., 2008. Effect of substituting shrimp waste hydrolysate of Penaeus merguensis for fish meal in broiler performance. Pak. J. Nutr. 7, 806-810, https://doi.org/10.3923/pjn.2008.806.810

Makhado R.A., Potgieter M.J., Wessels D.C.J., Saidi A.T., Masehela K.K., 2012. Use of mopane woodland resources and associated woodland management challenges in rural areas of South Africa. Ethnobot. Res. Appl. 10, 369-379

Makhado R.A., Potgieter M.J., Wessels D.C.J., 2009. Colophospermum mopane woodland utilisation in the northeast of Limpopo Province, South Africa. Ethnobot. Leaflets 13, 921-945

Manyeula F., Tsopito C., Kamau J., Mogotsi K.K., Nsoso S.J., Moreki J.C., 2013. Effect of Imbrasia belina (westwood), Tylosema esculentum (Burchell) Schreiber and Vigna subterranean (L) Verde as protein sources of growth and laying performance of Tswana hens raised under intensive production system. Sci. J. Anim. Sci. 2, 1-8

Manzano-Agugliaro F., Sanchez-Muros M.J., Barroso F.G., MartínezSánchez A., Rojo S., Pérez-Bañón C., 2012. Insects for biodiesel production. Renew. Sust. Energ. Rev. 16, 37443753, https://doi.org/10.1016/j.rser.2012.03.017

Mareko M.H.D., Nsoso S.J., Lebetwa N., 2008. Nutritive value of meat of guinea fowl raised on concrete and bare soil floors from 16-26 weeks of age. Res. J. Anim. Sci. 2, 5-11

Mareko M.H.D., Nsoso S.J., Mosweu K., Mokate K.K., Madibela O.R., 2010. Chemical composition and sensory evaluation of broilers supplemented on two levels of Phane worm (Imbrasia belina) meal. Bots. J. Agric. Appl. Sci. 6, 223-233

McDonald P., Edwards R.A., Greenhalgh J.F.D., Morgan C.A., 2002. Animal Nutrition. $6^{\text {th }}$ Edition. Pearson Education Limited. Harlow, Essex (UK)

Melo V., Garcia M., Sandoval H., Jiménez H.D., Calvo C., 2011. Quality proteins from edible indigenous insect food of Latin America and Asia. Emir. J. Food Agric. 23, 283-289

Mojeremane W., Lumbile A.U., 2005. The characteristics and economic value of Colophospermum mopane (Kirk ex Benth.) J. Léonard in Botswana. Pak. J. Biol. Sci. 8, 781-784

Moreki J.C., Tiroesele B., Chiripasi S.C., 2012. Prospects of utilizing insects as alternative sources of protein in poultry diets in Botswana: A review. J. Anim. Sci. Adv. 2, 649-658

Moreki J.C., van der Merwe H.J., Hayes J.P., 2011. Influence of dietary calcium levels on bone development in broiler breeder pullets up to 18 weeks of age. Online J. Anim. Feed Res. 1, 28-39

Moreki J.C., Dikeme R., Poroga B., 2010. The role of village poultry in food security and HIVIAIDS mitigation in Chobe District of Botswana. Livest. Res. Rural Dev. 22, \#55

Mufandaedza E., Moyo D.Z., Makoni P., 2015. Management of nontimber forest products harvesting: rules and regulations governing (Imbrasia belina) access in the South-Eastern Lowveld of Zimbabwe. Afr. J. Agric. Res. 10, 1521-1530, https://doi.org/10.5897/AJAR2013.7720

Mungkung R., Aubin J., Prihadi T.H., Slembrouck J., van der Werf H.M.G., Legendre M., 2013. Life cycle assessment for the environmentally sustainable aquaculture management: a case study of the combined aquaculture systems for carp and tilapia. J. Clean. Prod. 57, 249-256, https://doi.org/10.1016/j. jclepro.2013.05.029 
Mwimanzi L., Musuka C.G., 2014. The potential of mopani worm (Gonimbrasia belina) as an alternative protein source in fish feed. Int. J. Aquac. 4, 73-78, https://doi.org/10.5376/ ija.2014.04.0012

Nobo G., Moreki J.C., Nsoso S.J., 2012a. Growth and carcass characteristics of helmeted guinea fowl (Numida meleagris) fed varying levels of Phane meal (Imbrasia belina) as replacement of fishmeal under intensive system. Int. J. Agro Vet. Med. Sci. 6, 296-306

Nobo G., Moreki J.C, Nsoso S.J., 2012b. Feed intake, body weight, average daily gain, feed conversion ratio and carcass characteristics of helmeted Guinea fowl fed varying levels of phane meal (Imbrasia belina) as replacement of fishmeal under intensive system. Int. J. Poult. Sci. 11, 378-384, https://doi. org/10.3923/ijps.2012.378.384

Nsoso S.J., Mareko M.H.D., Manyanda S., Legodimo P.P., 2008. The effect of housing type on body parameters, feed intake and feed conversion ratio of guinea fowl (Numida melesgris) keets and chemical composition of their meat during growth and development in Botswana. Res. J. Anim. Sci. 2, 36-40

Nsoso S.J., Mareko M.H.D., Molelekwa C., 2006. Comparison of growth and morphological parameters of guinea fowl (Numida melesgris) raised on concrete and earth floor finishes in Botswana. Livest. Res. Rural Dev. 18, \#178

Olsen R.L., Hasan M.R., 2012. A limited supply of fishmeal: Impact on future increases in global aquaculture production. Trends Food Sci. Technol. 27, 120-128, https://doi.org/10.1016/j. tifs.2012.06.003

Oyegoke 0.O., Akintola A.J., Fasoranti J.O., 2006. Dietary potentials of the edible larvae of Cirina forda (westwood) as a poultry feed. Afr. J. Biotechnol. 5, 1799-1802

Pharithi M.T., Suping S.M., Yeboah S.O., 2004. Variations of the fatty acid composition in the oil from the larval stages of the emperor moth caterpillar, Imbrasia belina. Bull. Chem. Soc. Ethiop. 18 67-72, https://doi.org/10.4314/bcse.v18i1.61639

Pillay S., 2015. Mopane worm (Imbrasia belina) as indicators of elemental concentrations in a trophic system. Thesis of Master of Science. University of the Witwatersrand. Johannesburg (South Africa)

Premalatha M., Abbasi T., Abbasi T., Abbasi S.A., 2011. Energy-efficient food production to reduce global warming and ecodegradation: the use of edible insects. Renew. Sust. Energ. Rev. 15, 4357-4360, https://doi.org/10.1016/j.rser.2011.07.115

Raheem D., Carrascosa C., Oluwole O.B., Nieuwland M., Saraiva A. Millán R., Raposo A., 2018. Traditional consumption of and rearing edible insects in Africa, Asia and Europe. Crit. Rev. Food Sci. Nutr. https://doi.org/10.1080/10408398.2018.14401 91

Rapatsa M.M., Moyo N.A.G., 2017. Evaluation of Imbrasia belina meal as a fishmeal substitute in Oreochromis mossambicus diets: growth performance, histological analysis and enzyme activity. Aquac. Rep. 5, 18-26, https://doi.org/10.1016/j. aqrep.2016.11.004

Romero-Bernal J., Almaraz E.M., Ortega O.A.C., Salas N.P., GonzálezRonquillo M., 2017. Chemical composition and fatty acid profile in meat from grazing lamb diets supplemented with ryegrass hay, fishmeal and soybean meal as PUFA sources. Cienc. Rural 47, e20160533, https://doi.org/10.1590/0103-8478cr20160533

Rumpold B.A., Schlüter O.K., 2013. Potential and challenges of insects as an innovative source of food and feed production. Innov. Food Sci. Emerg. Technol. 17, 1-11, https://doi.org/10.1016/j. ifset.2012.11.005
Sánchez-Muros M.-J., Barroso F.G., Manzano-Agugliaro F., 2014 Insect meal as renewable source of food for animal feeding: a review. J. Clean. Prod. 65, 16-27, https://doi.org/10.1016/j. jclepro.2013.11.068

Sotak-Peper K.M., González-Vega J.C., Stein H.H., 2017. Amino acid digestibility in soybean meal sourced from different regions of the United States and fed to pigs. J. Anim. Sci. 95, 771-778, https://doi.org/10.2527/jas.2016.0443

Stack J., Dorward A., Gondo T., Frost P., Taylor F., Kurebgaseka N., 2003. Mopane worm utilisation and rural livelihoods in Southern Africa. In: Materials from The International Conference on Rural Livelihoods, Forests and Biodiversity, 19-23 May 2003, Bonn (Germany)

Steinfeld H., Wassenaar T., Jutzi S., 2006. Livestock production systems in developing countries: status, drivers, trends. Rev. Sci. Technol. 25, 505-516, https://doi.org/10.20506/rst.25.2.1677

Teles A.O., Lupatsch I., Nengas I., 2011. Nutritional and feeding of Sparidae. In: M.A. Pavlidis, C.C. Mylonas (Editors). Sparidae, Biology and Aquaculture of Gilthead Sea Bream and other Species. Blackwell Publishing Ltd. Oxford (UK), pp. 199-232, https://doi.org/10.1002/9781444392210.ch7

Thomas B., 2013. Sustainable harvesting and trading of mopane worms (Imbrasia belina) in Northern Namibia: an experience from the Uukwaluudhi area. Int. J. Environ. Stud. 70, 494-502, https:// doi.org/10.1080/00207233.2013.829324

Tlhong T.M., 2008. Meat quality of raw and processed guinea fowl. Thesis of Master of Science. Stellenbosch University, Stellenbosch (South Africa), pp. 62-66, https://scholar.sun. ac.za/handle/10019.1/1898

Tocher D.R., 2010. Fatty acid requirements in ontogeny of marine and freshwater fish. Aquacult. Res. 41, 717-732, https://doi. org/10.1111/j.1365-2109.2008.02150.x

van Eys J.E., Offner A., Bach A., 2004. Manual of Quality Analyses for Soybean Products in the Feed Industry. American Soybean Association. St. Louis, MO (USA)

van Huis A., van Itterbeeck J., Klunder H., Mertens E., Halloran A., Muir G., Vantomme P., 2013. Edible insects. Future prospects for food and feed security. FAO Forestry Paper 171. FAO. Rome (Italy), http://www.fao.org/3/i3253e/i3253e.pdf

Veldkamp T., Kwakkel R.P., Ferket P.R., Verstegen M.W.A., 2005. Growth responses to dietary energy and lysine at high and low ambient temperature in male turkeys. Poult. Sci. 84, 273-282, https://doi.org/10.1093/ps/84.2.273

Wessels D.C.J., van der Waal C., de Boer W.F., 2007. Induced chemical defences in Colophospermum mopane trees. Afr. J. Range Forage Sci. 24, 141-147, https://doi.org/10.2989/ AJRFS.2007.24.3.4.297

World Bank, 2013. Fish to 2030: prospects for fisheries and aquaculture. Agriculture and environmental services discussion paper no. 3. World Bank Group. Washington DC (USA), http://documents. worldbank.org/curated/en/458631468152376668/Fish-to2030-prospects-for-fisheries-and-aquaculture

Xiaoming C., Ying F., Hong Z., 2010. Review of the nutrition value of edible insects. In: P.B. Durst, D.V. Johnson, R.N. Leslie, K. Shono (Editors). Forest Insects as Food: Humans Bite back. Proceedings of a workshop on Asia-Pacific resources and their potential for development. 19-21 February 2008. Chiang Mai, Thailand. FAO Regional Office for Asia and the Pacific. Bangkok (Thailand), pp. 85-92

Yeboah S.O., Mitei Y.C., 2009. Further lipid profiling of the oil from the mophane caterpillar, Imbrasia belina. J. Am. Oil Chem. Soc. 86, 1047, https://doi.org/10.1007/s11746-009-1443-y 